\title{
The Effect Of Store Atmosphere On Purchase Decisions At Chirurgie Cafe And Books Medan
}

\author{
Pramesco Wiranta Sembiring
}

Department of Commerce/Business Administration Science, University Of North Sumatra, Indonesia.

\begin{tabular}{r}
\hline A R T I C L E I N F O \\
\hline Article history: \\
Received Mei 05, 2021 \\
Revised Jun 10, 2021 \\
Accepted Jul 30, 2021
\end{tabular}

Keywords:

Store Atmosphere Buying Decision

\begin{abstract}
This research is motivated by the importance of store atmosphere in a cafe or shop, because now the price, discount, promotion and service do not become guarantee of consumer to make a purchase, but store atmosphere (good store atmosphere) will be the main attraction for cafe Who own it, so as to attract consumers to make a purchase.The purpose of this research is to know the influence of store exterior, general interior, store layout and interior display to purchase decision at Chirurgie Cafe and Books Medan.This research uses quantitative method with associative approach. The population in this study were all visitors of Chirurgie Cafe and Books Medan with sample size 100 people. The sampling technique in this research is done by using Non Probability Sampling technique with accidental sampling technique and purposive sampling. Analytical methods used are validity test, reliability test, t-test, f-test, classical assumption test, multiple linear regression analysis test, and coefficient of determination (R2) test.The result of this research shows that partially the result of store exterior variables is tcount $(1,728)>$ ttable $(1,6608)$ and probability value $0,087<0,1$, which means that store exterior (X1) has positive and significant effect to purchasing decisions). The general interior variables show that tcount $(2.234)>$ ttable $(1.6608)$ and probability value $0.028<0.1$, which means that general interior (X2) has positive and significant effect to purchase decision $(\mathrm{Y})$. The store layout variable shows that tcount (2.2072)> ttable $(1.6608)$ and probability value $0.041<0.1$, which means that store layout (X3) has positive and significant effect on purchase decision $(\mathrm{Y})$. Exterior store variables show that tcount (0.397)> ttable (1.6608) and probability value $0.692<0.1$, which means that interior display $(\mathrm{X} 4)$ has positive but not significant effect on purchasing decision $(Y)$. Simultaneously the independent variable (free) shows that the fcount is 7.011 with the significance level 0.000 , while the ftable at the $90 \%$ confidence level $(\alpha=0.10)$ is 2.00 . Then fcount (7.011)> ftable (2.00) and probability value 0.000 $<0.10$, which means all independent variables simultaneously affect the dependent variable.
\end{abstract}

This is an open access article under the CC BY-NC license.

\section{Corresponding Author:}

Pramesco Wiranta Sembiring,

Department of Commerce/Business Administration Science,

University Of North Sumatra, Indonesia,

JI. Dr. Mansur No. 9 Padang Bulan, Kec. Medan Baru, Kota Medan 20222.

Email: wirantasembiring@gmail.com 


\section{INTRODUCTION}

Business is an activity or activity undertaken by a company to seek profit or added value. Currently the development of world business is getting higher. The development of this business is also experienced by the city of Medan. Various business activities began to emerge and develop, for example the property business, manufacturing business and no less growing is the culinary business. The culinary business is a business that is one of the choices for business people to run because it has good prospects. It can be seen with the proliferation of various types of businesses in the culinary field, ranging from large restaurants, street stalls to the most mushrooming today is the cafe culinary business.

Initially the cafe tradition came from Asian countries, especially the Middle East. It is recorded in history that in Mecca around the 16th century there were many cafes used for drinking coffee, a place to gather and discuss politics freely without any prohibition from the government as well as the availability of casual games such as chess games and reading poetry and stories. In addition there are also various activities that tend to be serious, but relaxed. The cafe in the past was not much different from the cafe model in today's era. We can see that wherever cafes currently are, there are poetry reading activities, book reviews, casual games, live music, stand up comedy, performances from famous artists and others, or just a place for some people to talk. talk at one table.

The competition that occurs among cafe businessmen is currently getting tougher. Competition is a form of business carried out in order to get a win or get a better position without having a physical collision or conflict. Business people must think of the right and effective strategy so that their business can still exist in the market and even develop better. Seeing the conditions of increasingly fierce competition, every cafe business needs to provide something different, by creating the uniqueness of its business compared to competitors in order to attract consumer interest in buying.

Consumers currently making purchases can not only be done by providing discounts, promotional activities, prices, food tastes, and service quality which are not a guarantee for consumers to make purchases. but store atmosphere (store atmosphere) is also the most important factor for consumers in choosing a place to dine. Store The cozy cafe atmosphere with unique and creative decorations is the main attraction for a cafe that makes consumers decide to visit the cafe and restaurant. A comfortable and calm atmosphere will be a consideration for consumers before deciding to come or visit a particular cafe.

We can see that the lifestyle of today's society is a modern lifestyle, especially for young people who make cafes a place to gather with friends. Middle-level students and college students have started to often hang out at the cafe from evening to night. They also often use the cafe as a place to discuss, dissect books, write, do assignments, and others. It is not uncommon for students and the public to use cafes as a place to celebrate their important days, such as birthdays, reunions, breaking the fast together in Ramadan and so on. In fact, not a few consumers prefer to eat at a cafe rather than eating at home on the grounds that they like the store atmosphere at the cafe.

\section{RESEARCH METHOD}

In this study the method used is associative research with a quantitative approach. Namely research that seeks to examine how a variable has a relationship or relationship with other variables. Is one variable the cause of changes in other variables.

\subsection{Reliability Test}

A questionnaire is said to be reliable or reliable if a person's answer to the statement is consistent or stable with the statement submitted. An indicator is said to be reliable if the indicator is used for the same subject, in different times and conditions, still showing the same results. If rcount $>$ rtable, then the questionnaire is declared reliable. On the other hand, if rcount $<$ rtable, then the questionnaire is declared unreliable. 


\subsection{Multiple Linear Regression Analysis}

In this study using multiple linear regression analysis method to determine the effect of two or more independent variables on the dependent variable. Multiple linear regression equations in general are:

$\mathrm{Y}=\mathrm{a}+\mathrm{b} 1 \mathrm{x} 1+\mathrm{b} 2 \times 2+\mathrm{b} 3 \times 3+\mathrm{b} 4 \times 4$

Information:

Y : Dependent Variable (Decision Purchase)

A : Score constant

b1,b2,b3 : Regression coefficient, increase or decrease in dependent variable

(Y) X1 : Independent variable (Store Exterior)

X2 : Independent variable (General Interior)

X3 : Independent variable (Store Layout)

X4 : Independent variable (Interior Display)

\subsection{Kcoefficient of determination (R2)}

The coefficient of determination (R2) is used to see the comparison between the $Y$ variables described by $\mathrm{X} 1, \mathrm{X} 2, \mathrm{X} 3$ and $\mathrm{X} 4$ together compared to the total variable $\mathrm{Y}$. If other than $\mathrm{X} 1, \mathrm{X} 2, \mathrm{X} 3$ and $X 4$ all variables outside the model contained in $E$ are included. into the model, then the value of R2 will be 1 . The results of the Adjusted R2 calculation can be seen in the Model Summary output. In the Adjusted R2 column, it can be seen how many percentages can be explained by the independent variables to the dependent variable. While the rest is influenced or explained by other variables that are not included in the research model.

\section{RESULTS AND DISCUSSIONS}

\subsection{Hypothesis testing}

\section{a. Partial Significance Test (t-test)}

Partial significant test (t-test) was conducted to see partially (individually) the effect of the independent (free) variables, namely store exterior, general interior, store layout, interior display on the dependent variable (bound), namely purchasing decisions. If tcount $>$ ttable then $\mathrm{HO}$ is rejected and $\mathrm{Ha}$ is accepted, whereas if tcount < ttable then $\mathrm{Ho}$ is accepted and $\mathrm{Ha}$ is rejected.

The t-test can also be seen based on the level of significance, namely if the calculated probability value is $<0.1$ (sign. $<\mathrm{a} 0.1$ ), then $\mathrm{H} 0$ is rejected and $\mathrm{Ha}$ is accepted. On the other hand, if the calculated probability value is $>0.1$ (sign. < a 0.1 ), then $\mathrm{HO}$ is accepted and $\mathrm{Ha}$ is rejected. The value with $d f=n-k$ is $100-4=96$, so the value of the significant level of $10 \%$, namely ttable is 1.6608. The results of the $t$ test can be seen in the following table:

Table 1. Partial Significance Test Results (t Test) Coefficientsa

\begin{tabular}{|c|c|c|c|c|c|c|}
\hline \multirow{7}{*}{1} & \multirow[b]{2}{*}{ Model } & \multicolumn{5}{|c|}{ Standardized } \\
\hline & & B & Std. Error & Beta & $\mathrm{T}$ & Sig. \\
\hline & (Constant) & 17,932 & 5.098 & & 3,517 & .001 \\
\hline & TOTAL.X1 & .221 & .128 & 177 & 1,728 & .087 \\
\hline & TOTAL.X2 & .370 & .166 & .228 & 2.234 & .028 \\
\hline & TOTAL.X3 & .450 & .217 & .207 & 2.072 & .041 \\
\hline & TOTAL.X4 & .159 & .401 & .038 & .397 & .692 \\
\hline
\end{tabular}

Based on table 1 above, it can be concluded that: $t$ valuecount for the store exterior variable of 1.728 with a significance of 0.087 . While the t table at $=0.1$ is 1.6608 . This shows that tcount $(1.728)>$ ttable (1.6608) and the probability value is $0.087<0.1$, so $\mathrm{HO}$ is rejected and $\mathrm{Ha}$ is accepted. Thus, it can be concluded that the store exterior (X1) has a positive and significant effect 
on purchasing decisions $(\mathrm{Y})$. A positive coefficient value indicates that the store exterior $(\mathrm{X} 1)$ has a positive and significant effect on purchasing decisions $(Y)$. This means that an increase in the store exterior variable (X1) can improve purchasing decisions.

1) $t$ valuecount for the general interior variable of 2.234 with a significance of 0.028 . While the $t$ table at $=0.1$ is 1.6608 . This shows that tcount $(2.234)>$ ttable (1.6608) and the probability value is $0.028<0.1$, so $\mathrm{H} 0$ is rejected and $\mathrm{Ha}$ is accepted. Thus, it can be concluded that the general interior (X2) has a positive and significant effect on purchasing decisions $(\mathrm{Y})$. A positive coefficient value indicates that the general interior $(\mathrm{X} 2)$ has a positive and significant effect on purchasing decisions $(\mathrm{Y})$. This means that an increase in the general interior variable (X1) can improve purchasing decisions.

2) $t$ valuecount for the store layout variable of 2.2072 with a significance of 0.041 . While the $\mathrm{t}$ table at $=0.1$ is 1.6608 . This shows that tcount $(2.2072)>$ ttable (1.6608) and the probability value is $0.041<0.1$, so $\mathrm{HO}$ is rejected and $\mathrm{Ha}$ is accepted. Thus, it can be concluded that the store layout (X3) has a positive and significant effect on purchasing decisions (Y). A positive coefficient value indicates that the store layout (X3) has a positive and significant effect on purchasing decisions $(Y)$. This means that an increase in the store layout variable (X3) can improve purchasing decisions.

3) $t$ valuecount for the store exterior variable of 0.397 with a significance of 0.692 . While the $\mathrm{t}$ table at $=0.1$ is 1.6608 . This shows that tcount $(0.397)>t$ table $(1.6608)$ and the probability value is $0.692<0.1$, so $\mathrm{HO}$ is rejected and $\mathrm{Ha}$ is accepted. Thus, it can be concluded that the interior display (X4) has a positive but not significant effect on purchasing decisions $(\mathrm{Y})$. A positive coefficient value indicates that the interior display $(X 4)$ has a positive but not significant effect on purchasing decisions $(Y)$. This means that an increase in the interior display variable (X4) can improve purchasing decisions.

\section{b. Simultaneous Significant Test (F-Test)}

Simultaneous significant test (F-test) was used to test whether the variable store exterior (X1), general interior (X2), store layout (X3) and interior display (X4) had a simultaneous effect on purchasing decisions $(\mathrm{Y})$ at chirurgie cafe and books Medan. If fcount $<\mathrm{ftable}$ then $\mathrm{Ho}$ is accepted and $\mathrm{Ha}$ is rejected.

The $\mathrm{F}$ test can also be seen based on the level of significance, that is, if the calculated probability value is $<0.10$ (sig. $<0.10$ ), then $\mathrm{Ho}$ is rejected and $\mathrm{Ha}$ is accepted. On the other hand, if the calculated probability value is $>0.10$ (sig. $>0.10$ ), then $\mathrm{Ho}$ is accepted and $\mathrm{Ha}$ is rejected.

f Nilai valuetable at $=10 \%$ is 2.00 . While the value of fcount will be obtained using the help of a statistical program which can be seen in the following table:

Table 2. Simultaneous Significant Test Results (F-Test)

\begin{tabular}{ccccccc}
\multicolumn{7}{c}{} \\
\hline & Model & Sum of Squares & Af & Mean Square & F & Sig. \\
\hline 1 & Regression & 394,772 & 4 & 98.693 & 7.011 & $.000 \mathrm{~b}$ \\
& Residual & 1337,228 & 95 & 14.076 & & \\
& Total & 1732,000 & 99 & & & \\
\hline
\end{tabular}

a. Dependent Variable: TOTAL.Y

b. Predictors: (Constant), TOTAL.X4, TOTAL.X3, TOTAL.X2, TOTAL.X1

Based on table 2 above, it can be seen that fcount of 7,011 with a significance level of 0.000 . While the ftable at the $90 \%$ confidence level $(\alpha=0.10)$ is 2.00 . Then fcount $(7.011)>$ ftable $(2.00)$ and the probability value is $0.000<0.10$ so that $\mathrm{Ho}$ is rejected and $\mathrm{Ha}$ is accepted. This shows that the independent variables (independent) namely store exterior, general interior, store layout, and interior display simultaneously affect the dependent variable (bound), namely purchasing decisions. Thus, store exterior, general interior, store layout, and interior display can improve purchasing decisions at chirurgie cafe and books Medan. However, if one of the variables decreases, it can also reduce purchasing decisions.

\section{c. Coefficient of Determination (R2)}


The coefficient of determination is used to see the ability of the independent variables, namely store exterior, general interior, store layout, and interior display, explaining the dependent variable, namely purchasing decisions. Where is the Adjusted value

Table 3. Coefficient of Determination Test Results (R2)

\begin{tabular}{ccccc}
\multicolumn{4}{c}{ Model Summary } \\
\hline Model & $\mathrm{R}$ & $\mathrm{R}$ Square & Adjusted R Square & $\begin{array}{r}\text { Std. Error of the } \\
\text { Estimate }\end{array}$ \\
\hline 1 & $.477 \mathrm{a}$ & .228 & .195 & 3,752 \\
\hline $\begin{array}{l}\text { a. Predictors: (Constant), TOTAL.X4, TOTAL.X3, TOTAL.X2, TOTAL.X1 } \\
\text { Source: Data Processing Results, } 2017\end{array}$ &
\end{tabular}

Based on table 3 above, it can be concluded that:

1) $R$ value of 0.477 means the relationship between store exterior $\left(X_{1}\right)$, general interior $(X 2)$, store layout (X3), and interior display (X4), on purchasing decisions $(\mathrm{Y})$ of 0.477 . This means that the relationship between variables is quite close.

2) The value of $R$ Square is 0.228 . This means that $22.8 \%$ of purchasing decisions at chirurgie cafe and books Medan can be influenced by store exterior (X1), general interior (X2), store layout (X3), and interior display (X4). While the remaining $77.2 \%$ is influenced by other variables that are not included in this study.

\subsection{Influence of Store Exterior on Purchase Decision}

Based on the results of the study, the results were obtained in hypothesis testing using t-test analysis which showed the value of tcount $>$ ttable with a value of $1.728>1.6608$ with sig 0.087 $<0.1$. This proves that $\mathrm{Ha}$ is accepted, then there is a positive and significant effect of the store exterior variable on purchasing decisions at chirurgie cafe and books Medan. That is, the better the store exterior in a cafe or store, the more consumers will make purchases at the store or cafe. This is in line with the research conducted by Sri Ayu Cahyani entitled "The Effect of Store Atmosphere on Giant Consumer Purchase Decisions in Makassar City". The results of hypothesis testing the Store Exterior variable affect purchasing decisions with the results of the tcount value of 2 ,

Thus the influence of the store exterior has a positive impact on purchasing decisions. In accordance with the theory put forward by Berman and Evans in Fuad (2010: 3) Store exterior is the front of the store that reflects the stability and robustness of the company's spirit and the nature of the activities in it, and can create trust and goodwill for consumers. recognition sign, so it often expresses a symbol. With a good store exterior from a cafe, it will be able to attract consumers to make purchases and consumers have good trust in the cafe or shop.

\subsection{Influence of General Interior on Purchase Decision}

Based on the results of the study, the results obtained on hypothesis testing using t-test analysis which showed the value of tcount $>$ ttable with a value of $2.234>1.6608$ with sig 0.028 $<0.1$. This proves that $\mathrm{Ha}$ is accepted, then there is a positive and significant influence on the general interior variable on purchasing decisions at chirurgie cafe and books Medan. That is, the better the general interior in a cafe or shop, the more consumers make purchases at the shop or cafe. This is in line with the research conducted by Sri Ayu Cahyani entitled "The Effect of Store Atmosphere on Giant Consumer Purchase Decisions in Makassar City". The results of hypothesis testing the general interior variable affect purchasing decisions with the tcount value of 2,665. These results indicate that Store Exterior has a significant and positive effect on purchasing decisions at Chirurgie Cafe and Books Medan.

Thus the general interior influence has a positive impact on purchasing decisions. In accordance with the theory put forward by Berman and Evans in Fuad (2010: 3), a good general interior display is one that can attract the attention of consumers and help them to easily observe, examine and select goods and finally make a purchase when consumers enter the store. shop. With a good general interior and good room arrangement it will be able to make consumers make purchases. 


\subsection{Influence of Store Layout on Purchase Decision}

Based on the results of the study, the results obtained in hypothesis testing using t-test analysis which showed the value of tcount $>$ ttable with a value of $2.072>1.6608$ with sig 0.041 $<0.1$. This proves that $\mathrm{Ha}$ is accepted, then there is a positive and significant influence of the store layout variable on purchasing decisions at chirurgie cafe and books Medan. That is, the better the store layout in a cafe or shop, the more consumers make purchases at the shop or cafe. This is in line with the research conducted by Sri Ayu Cahyani entitled "The Effect of Store Atmosphere on Giant Consumer Purchase Decisions in Makassar City". The results of hypothesis testing the store layout variable have an effect on purchasing decisions with the tcount value of 2.062.

\subsection{Influence of Interior Display on Purchase Decision}

Based on the results of the study, the results obtained on hypothesis testing using t-test analysis which showed the value of tcount $>$ ttable with a value of $0.397<1.6608$ with a sig of $0.692>0.1$. This proves that $\mathrm{Ha}$ is accepted, so there is a positive but not significant effect of the interior display variable on purchasing decisions at chirurgie cafe and books Medan. That is, the better the interior display in a cafe or shop, the more consumers make purchases at the shop or cafe. Because the interior display is all the instructions in the store and can make it easier for consumers to find out the instructions in the store or cafe. This is in line with the research conducted by Sri Ayu Cahyani entitled "The Effect of Store Atmosphere on Giant Consumer Purchase Decisions in Makassar City". The results of testing the hypothesis that the interior display variable has an effect on purchasing decisions with the results of the tcount value of 2.107. These results indicate that Store Layout has a significant and positive effect on purchasing decisions at Chirurgie Cafe and Books Medan.Thus the influence of store layout has a positive impact on purchasing decisions.

\subsection{Influence Store Exterior, General Interior, Store Layout, Interior Display Against Purchase Decision}

Based on the results of the study, the results of hypothesis testing using $\mathrm{F}$ test analysis showed that the fcount value was 7.011 with a significance level of 0.000 . While ftable $(\alpha=0.10)$ is 2.00. Then fcount $(7.011)>$ ftable $(2.00)$ and the probability value is $0.000<0.10$ so that $\mathrm{Ha}$ is accepted. This can prove that the independent variables (store exterior, general interior, store layout, interior display) together (simultaneously) have a positive and significant effect on the dependent variable (purchase decisions). Based on the results of research through testing the coefficient of determination (R2) shows that the store exterior, general interior, store layout, interior display together contribute $22.8 \%$ to purchasing decisions and the remaining 77 .

\section{CONCLUSION}

Partially, the store exterior variable (X1) has a positive and significant effect on purchasing decisions $(Y)$ at chirurgie cafe and books Medan has been proven through the results of hypothesis testing using t-test analysis which shows the value of tcount $>$ ttable.

Partially, the general interior variable (X2) has a positive and significant effect on purchasing decisions $(Y)$ at chirurgie cafe and books Medan has been proven through the results of hypothesis testing using t-test analysis which shows the value of tcount $>$ ttable.

Partially, the store layout variable (X3) has a positive and significant effect on purchasing decisions $(Y)$ at chirurgie cafe and books Medan has been proven through the results of hypothesis testing using t-test analysis which shows the value of tcount $>$ ttable.

Partially, the interior display variable (X4) has a positive but not significant effect on purchasing decisions $(\mathrm{Y})$ at chirurgie cafe and books Medan has been proven through the results of hypothesis testing with 5 . using t-test analysis which shows the t-count value is positive but not significant.

Simultaneously, the variables store exterior (X1), general interior (X2), store layout (X3), and interior display (X4) have a positive and significant effect on purchasing decisions $(\mathrm{Y})$ at Chirurgie 
cafe and books Medan has been proven through the results in hypothesis testing using $\mathrm{F}$ test analysis which shows the value of fcount $>$ ftable.

\section{REFERENCES}

Achmad Indra Widyanto, Edy Yulianto, Sunarti Jurnal Administrasi Bisnis PENGARUH STORE ATMOSPHERE TERHADAP KEPUTUSAN PEMBELIAN (Survei pada Konsumen Distro Planet Surf Mall Olympic Garden kota Malang).

Ajeng Wind, Sabirin Wardhana. 2015. Inilah Saatnya Bisnis Kafe, Gaya Anak Muda. Jakarta: PT Grasindo.

Amirullah. 2002. Perilaku Konsumen. Graha IImu, Yogyakarta.

Berman, B., Evans, J. R. 2007. Retail management: A strategic approach. New Jersey: Prentice Hall

Fuad, Muhammad. 2010. Store Atmosphere dan Perilaku Pembelian Konsumendi Toko Buku Gramedia Malang. Jurnal Manajemen Pemasaran Modern.Vol. 2, No. 1, Januari-Juni. Hal. 1-14.

Kurniawan, D.\& Kunto, Y. S. 2013. Pengaruh promosi dan store atmosphere terhadap impulse buying dengan shoping emotion sebagai variabel intervening studi kasus di Matahari Department Store cabang Supermall Surabaya. Jurnal Manajemen Pemasaran Petra,1(2),1-8. Surabaya: Universitas Kristen Petra.

Levy, M., Weitz, B. A. 2007. Retailling management (4th ed.). New York: McGraw-Hill//rwin

Ma'ruf, H. 2006. Pemasaran ritel (2nd ed.). Jakarta: Gramedia Pustaka Utama.

Mowen, J.C, Michael, M. 2002. Perilaku konsumen (5 th ed.) .(Dwi Kartika Yahya, Trans.). Jakarta: Penerbit Erlangga

Nuraini Azizah PENGARUH STORE ATMOSPHERE TERHADAP KEPUTUSAN PEMBELIAN (Studi pada Konsumen Restoran Pringsewu Yogyakarta) Universitas Muhammadiyah Purworejo.

Philip Kotler, Kevin Lane Keller. 2009. Manajemen Pemasaran, Edisi Ketiga belas, jilid 1. Jakarta: Erlangga.

Schiffman, Leon, Kanuk Leslie Lazar. 2008. Perilaku Konsumen. Edisi ketujuh. Cetakan keempat. Jakarta: PT Indeks

Simamora, Bilson. 2003. Membongkar Kotak Hitam Konsumen. Jakarta: Gramedia Pustaka Utama.

Sugiyono. 2008. Metode penelitian bisnis: Pendekatan kuantitatif, kualitatif. Bandung: Alfabeta.

Sunyoto, danang. 2015. Manajemen Bisnis Ritel. Yogyakarta: CAPS Umar, Husein. 2014 Metode Penelitian untuk Skripsi dan Tesis Bisnis. Jakarta: PT. Raja Grafindo Persada.

Utami Christina Whidya.2006. Manajemen Ritel: Strategi dan Implementasi Ritel Modern. Jakarta:Salemba Empat.

Vitta Maretha, Engkos Achmad Kuncoro PENGARUH STORE ATMOSPHERE DAN STORE IMAGE TERHADAP KEPUTUSAN PEMBELIAN KONSUMEN PADA TOKO.

BUKU GRAMEDIA PONDOK INDAH Jurusan Manajemen, Fakultas Ekonomi dan Bisnis, Bina Nusantara University. 